DOI: https://10.15407/kvt198.04.078

UDC 004.75+004.932.2:616

KOVALENKO O.S. ${ }^{1}$, DSc (Medicine), Professor,

Head of the Medical Information Systems Department

e-mail: askov49@gmail.com

MISHCHENKO R.F. ${ }^{2}$, $\mathrm{PhD}$ (Medicine),

Physician of Info-analytical Department of Medical Statistics

e-mail: roman.mishchenko@gmail.com

KOZAK L.M. ${ }^{1}$, DSc (Biology), Senior Researcher,

Leading Researcher of the Medical Information Systems Department.

e-mail:1mkozak52@gmail.com

${ }^{1}$ International Research and Training Centre for Information Technologies

and Systems of the National Academy of Sciences of Ukraine

and Ministry of Education and Science of Ukraine,

40, Acad. Glushkov av., Kyiv, 03187, Ukraine

${ }^{2}$ Khmelnytsky Regional Hospital,

1, Pilotska st., Khmelnytskyi, 29000, Ukraine

\title{
TRANSFORMATION OF CLINICAL DECISION SUPPORT SYSTEMS INTO FHIR STRUCTURES TO ENSURE QUALITY OF MEDICAL CARE
}

Introduction. The reform of the medical sector in Ukraine has given impetus to the development of eHealth and, as a consequence, the creation of medical registers systems and specialized medical information systems to support the operation of primary health care etc. One of the strategic directions of the health care system is to find and choose effective methods of managing the quality of care.

The purpose of the paper is to analyze the conditions and opportunities for transformation of the clinical decision support system using standard Fast Healthcare Interoperability Resources (FHIR) structures to ensure health care quality control.

Results. The current level of medical information systems development requires the application of the international standard FHIR, which are applied for the exchange of data between different systems of electronic medical records and between different components of the same electronic medical record (EMR) system, for standardization of interoperability.

Uninterrupted improvement model, known as the Plan-Do-Check-Act (PDCA), which consists of four components - planning, executing, testing and improving own process, is considered. The characteristics of the FHIR standard are analyzed and ways of transforming the clinical decision support system based on this standard are identified. The concept of an abstract data node, ensuring terminological compliance, implementation of the Workflow data model, and other functions and tasks of the clinical decision support system are described.

Conclusions. One of the important areas of eHealth development is to implement the information systems forcare quality managing based on modern information medical standards. Creation and implementation of effective methods for monitoring (identifying) diagnostic and treatment quality

(C) O.S. KOVALENKO, R.F. MISHCHENKO, L.M. KOZAK, 2019 
in hospital will foster optimization and increase of their activity efficiency.

The use of the FHIR framework in the creation of information support system for evaluating the care quality enables to improve the data exchange quality and their processing for decision-making.

Keywords: eHealth, FHIR structures, clinical decision support system, health care quality control.

\section{INTRODUCTION}

The digital transformation of society has also touched such an important area as healthcare. Against this background, digital medicine, covering virtually all areas of the health care system has emerged.

The reform of the medical sector in Ukraine has given impetus to the development of eHealth and, as a consequence, the creation of medical registers systems and specialized medical information systems to support the operation of primary health care etc.

One of the strategic directions of the health care system is to find and choose effective methods of managing the quality of care. National programs for improving quality of health care have been developed in a number of countries based on the use of information standards to solving these problems. Let us mention the Veterans Health Administration (VHA) program of the Quality Study (QUERI), which aim sat ensuring excellence in all areas where the VHA provides medical services, including inpatient, outpatient and long-term care. Significant emphasis is placed on the role of information systems in the health care quality estimation [1]. An analysis of published studies on the PubMed, Scopus, Cochrane Library, and other databases has shown a significant impact of the electronic medical records (EMR) use on health care quality, primarily reducing the time on documentation [2].

According to WHO definition, the most important criteria for quality of care are the degree of reduction of the risk of possible disease, progression of the existing disease, the development of complications due to the disease, examination and treatment, taking into account the optimal use of available medical resources and technologies, as well as the patient's satisfaction with the medical care [3-7]. The importance of making evidence-based decisions resulting from monitoring and indepth analysis of information which comes from using a variety of software is essential for the implementation of guarantees and the quality of care. However, so far, there is no general position in the Ukrainian healthcare facilities on implementing the continuous quality improvement concept. Mechanisms of ensuring a guaranteed level of care quality are underway. Elements of information infrastructure are being created for the medicine needs, the beginning of development, application and spreading modern information means for health care has been done [8]. However, developed information systems tend to be narrowly focused on supporting separate functions and tasks, there is no unified approach to these systems development for united information medical environment $[9,10]$.

The topicality of this problem is due to its extreme importance for one of the most expensive and resource-intensive types of medical care - inpatient care. Creation and implementation of effective methods for monitoring quality of the diagnosis and treatment in hospitals will allow to optimize and increase their efficiency.

Therefore, one of the important areas of eHealth development is to implement the information systems for care quality managing based on modern information medical standards. 


\section{PROBLEM STATMENT}

Healthcare information technology (IT) tools that support the assessment of medical care quality (QI) allow us to measure, track, analyze the effectiveness of medical care and monitor the improvement of clinical process, influence on the overall patients' health and the coordination of medical care, the attempt to reduce costs and improve the health of the patient. Such tools are based on EMRs with structured data. These structured EMRs can be used to collect baseline data and to analyze, report and track data [11].

The use of EMRs is the basis for the development of various information resources. Registries (e.g., for specific diseases, immunizations, prevention and procedures) help to identify care gaps for the maximum benefit for patient and for improving the organization of such care. For the most effective work, registries must be interconnected and integrated into the workflows of practical medicine. Electronic medical records accumulate data of laboratory results, vaccination, medication use, and other patient care information. This information may be provided to other healthcare facilities and medical professionals to coordinate care for different patients.

Decision support systems based on effective digital medicine techniques for EMF analysis are capable of improving the health care quality. Clinical Decision Support System (CDSS) is an independent set of medical information system (MIS) components focused on information support for clinical and economic decision making. Such systems implementation has already shown their importance in managing the treatment process quality and in providing evidence for medical recommendations [12-15].

Today, all information systems have to meet certain standards of the exchange of information and data, the electronic records format, the information protection etc. One of the most common standards for the exchange of medical data and information is the Health Level 7 standard (HL7), a number of its versions also regulate electronic medical records formats [16].

The current level of medical information systems development requires the application of the international standard FHIR, which are applied for the exchange of data between different systems of electronic medical records and between different components of the same EMR system, for standardization of interoperability, as well as for the implementation of the functional model EMR [17].

The FHIR standard is a development of the HL7 standard, the changes in the set, new extensions, and a formal profile added to the first previous versions of FHIR to express basic minimum metadata. In 2014, the first draft of the standard for trial use (DSTU1 0.0.82) was issued. "DSTU Version 2 QA Preview, Aug 31 2015" had major changes regarding transaction integrity, URL resolution rules were changed, new and altered data types, new and changed internal resources (regarding patient records, reviews, and techniques, diagnosis and treatment plans, etc.) were specified. Then, for several years, work was done to improve the new standard, using the experience of its implementation in practical medicine. The FHIR R4 version has been in force since December 2018, with many significant changes compared with the first regulatory content [18]. 
The main FHIR elements are the modular components - Resources. By analogy with "the set of blocks", these Resources build specific systems that meet the requirements of the healthcare facility and provide easier solutions to current clinical and administrative issues. FHIR is suitable for use in a wide variety of contexts applications for mobile phones, cloud communications, EMR-based data sharing, server communication with major healthcare facilities, and more [19, 20].

One of the FHIR implementations is the OncoWorkStation (OWS) Chemotherapy Planning System, which implements a PlanDefinition as block diagram for the choice of treatment regimen and implementation of the Order Set with the generation of a highly differentiated personal CarePlan for chemotherapy worksheet $[3,4]$. The system has been used effectively for several years and with adaptation to the specifics of various German clinics in adult and pediatric practice. OWS chemotherapy plans include about 100-150 treatment regimens in adult oncology and $24-28$ (98 \% of all available) regimens in pediatrics. OWS plans implemented a section of medication prescriptions permitted at the time of implementation of the clinical protocols. They consisted of flowcharts of treatment regimens and direct sets of orders that generated CarePlan. The "EventCondition-Action" rules (ECA) were overwhelmingly concerned with changes in chemotherapy doses or medications depending on laboratory or patient data.

In OWS, the rules were stored not as a program code, but as a database node as part of an action plan. This database structure was read and interpreted as rules.OWS automated verification has not been considered or implemented. Improvement of this system was carried out according to the results of its practical use.

Summarizing, clinical practice processes and their organization consist of structured procedures for measuring and reporting results at the health facility and at the physician level. Improving these processes and adapting to daily practice is based on evaluating the health care quality that activates feedback to improve patient care. The use of FHIRs will increase the efficiency of data exchange between all participants in the healthcare process.

The purpose of the paper is to analyze the conditions and opportunities for transformation of the clinical decision support system using FHIR structures to ensure health care quality control.

\section{MODEL OF UNITERRUPTED IMPROVEMENT AS THE BASIS OF IMPROVING THE TREATMENT AND DIAGNOSIS QUALITY}

The quality of the diagnostic and treatment processes, like any other process, is achieved by the cyclic application of a uninterrupted improvement model, known as the Plan-Do-Check-Act (PDCA), which consists of four components - planning, executing, testing and improving own process [21].

According to the requirements of the IT industry development, the treating process reflection is carried out by the business process flows method.

Creating high-quality workflows is a cyclical process of their formal description, integration of these workflows during medical documentation in hospital, gathering information on the implemented measures effectiveness, using information needed to improve them, their updating on the basis of collected world and own data. 
The medical-diagnostic process description, from the FHIR, is the sequence of EMRs on completion of each of its components, recording of the medical condition (Condition), of the examinations, analyzes (Observation), appointments (CarePlan) in the format described in the Clinical Module FHIR. Electronic medical record is the main component of MIS, on the basis of which all other modules of treatment quality providing are built. The FHIR architectural framework provides data models and recommendations for the implementation of each of these parts.

Treatment planning. The expertise and experience of the treating physician are the key component of the care quality. Modern MIS uses the implementation of the FHIR specification to define and execute an action plan (AP) for organizing and managing workflows, enables the physician or group of physicians to present their expertise of the treating process in the form of computerized action plans. These plans are the first and the main component of quality assurance, according to the Deming cycle.

Meta-Content-Relational Database Model (MCR-DB) was developed on the basis of relational database, using five types of constraints for the primary and secondary key of the abstract data node, for implementing all the necessary FHIR structures, achieving NoSQL database functionality and solving other tasks of the healthcare institution.

The Workflow FHIR module and the Clinical Reasoning module of the FHIR framework describe data models and modes that allow them to formally express physician knowledge, interactively use it to guide the treating process, and make it possible to evaluate and improve them. The workflow in FHIR is defined in a declarative programming paradigm in which the structures and elements of a computer program express the calculation logic without describing the sequence of its execution.

Workflow is an algorithm defined in the format of a separate structure Plan Definition, as a set of tasks (Task) to collect and analyze the data needed to make the right clinical decision, as well as documenting the actions to ensure the treatment process, in accordance with the level of knowledge at the time of their creation. The peculiarity of these algorithms is that they are executed interactively - partly programmatically, partly by person.

The tasks are grouped into blocks that are the workflow process nodes at the same time and in the same logical space.

Formalized action plans are divided into different types, usually by their field of use. Simple Action Plans are: organizational communication (Order Set of Surveys or Assignments), status assessment (ECA rule sets), etc. Comprehensive action plans are the patient routes, computerized clinical protocols. Different types of action plans are often combined.

The implementation of computerized plans for medical treatment is interactive. Software implementation of the action plan is prescribed in the paradigm of event-oriented programming by determining the event template (Event Definition, Event) and the user, in the form of a trigger (Trigger Definition) to track the event. Event templates prescribe ECA rules for interpreting certain electronic medical records or their groups as requiring activity events. Events can be defined as separate system elements or specific components of some action plans. 
The AP tasks fulfillment after their activation is carried out in stages preserving the statuses of fulfillment (Workflow State): "in process", "request is made", "answer is sent", "accepted", "rejected"; "completed", "failed", "canceled".

To formulate action plans, tasks are defined in such a way that, as a result of their fulfillment, they are stored in the corresponding medical documents (Documents) as electronic medical records of the specified coding systems.

Action plans can be implemented either directly sequentially for the implementation of the treatment process or indirectly, for comparison with existing electronic medical records and plans, as well as for finding unfulfilled or unconfirmed items of tasks.

The validation of the treatment process consists of two parts: control of the correctness of the action plans execution by audit (Audit Event) and the collection of information needed to improve the action plans according to pre-planned data collection in FHIR format (Measure). Measurements and audits can be applied to any AP element: tasks, rules, assignments, etc.

Improving the treating process is a scientifically founded, guided creative process for improving action plans. This process is based on the collected personal and world information (knowledge) of evidence-based medicine. Improvement of existing action plans is provided by the proper organization and use of internal clinical audit.

Improvements to the plans themselves are achieved using the Deming PDCA approach, which enables purposeful measurements of results and their statistical processing by various methods: data stratification, finding the data significance (Pareto diagram) and cause and effect relationships (Ishikawa diagrams) or comparison of world evidence-based medicine.

\section{CHARACTERISTICS AND POSSIBILITIES OF THE FHIR STANDARD APPLICATION IN THE CLINICAL DECISION SUPPORTIIIG SYSTEM}

FHIR approach to CDSS implementation and clinical quality framework. As noted, quality management is implemented using an EMR by maintaining links with relevant additional data structures. The EMR Task Plans link shows which CDSS programs were used for this purpose.

The Clinical Quality Framework adds the opportunity to extend the relevant Measure tasks to test the effectiveness of the use of particular clinical recommendations or to collect data for improving them.

Recoverable Data linking combines the essence, activities, and agents underlying CDSS debugging and clinical auditing, forms the evaluation basis for authentication, on the semantic network (W3C PROV).

The CDSS tasks complexity and clinical quality frameworks require an internal scripting language to navigate data structures such as XPath and Clinical Quality Language (CQL).

Knowledge presentation is a component that provides perceptions and interoperability of formally described action plans, event-state-action rules system, order sets (evidence-based clinical checklists, clinical protocols), and are an integral part of the CDSS user interface. 
Implementation of the FHIR approach to the clinical decision support system. To implement the described requirements of MIS, it is necessary to create a database, which, in addition to preserving EMR function, must ensure that the body of the program and the trace for its fulfillment are stored in the DB nodes. To do this, we suggest using a meta-content-relational database model.

The program body preservation is interpreted during their analysis, such as s-expressions, in LISP-style, that makes it possible to define both data and procedures. The trace of such programs execution is stored not in RAM, but in the database for further verification.

Data trace statistical analysis gives an opportunity to evaluate the use frequency and its authenticity (clinical audit) as well as to process the measurements for proving the treatment effectiveness, as well as identifying new treatment quality indicators to further improve the program action plans.

The application of the three components of the relational database configuration capability enables the creation of a meta-content-relational database model based on the relational database as the necessity for the specified requirements implementation.

It is appropriate to investigate the ability of using FHIR for implementing the Clinical Query Language requirements. MCR-DB uses one single primary key (id) for all database tables.

The concept of abstract data node. The prerequisite for the proposed model implementation is the use of a single primary key for all database tables.

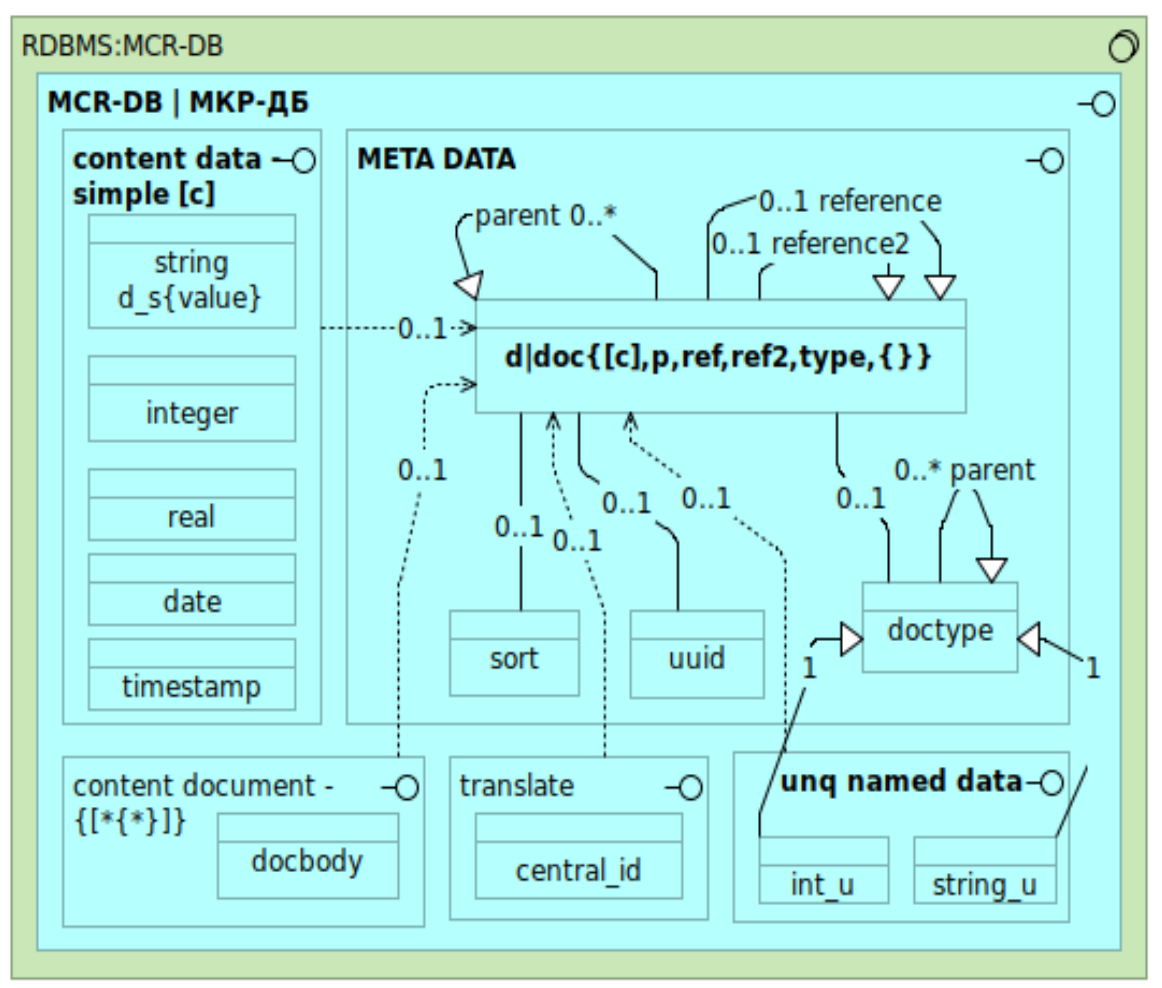

Fig. 1: Meta-content-relational database model 
The concept of an abstract data node is introduced:

$\mathrm{ADN} \mid \mathrm{ABД} \quad \operatorname{doc}\{[\mathrm{c}], \mathrm{p}$, ref, ref2, type, \{\}$\}$ alias doc $\mid \mathrm{d}$ is a META DATA group.

The sequence of keys inside \{\} is selected according to the frequency of use to be kept, as in case of the use of () to call functions.

Note the properties of the keys. Linking AVD $0 . . n$ to content [c] is by using the first key of the link d.id :[c.id] with tables with one simple type field - content data group - simple[c].

The second key that organizes tree structure of the parentp :doc.id $0 .{ }^{*}$ data is the most commonly used, third and fourth keys with reference to other nodes ( $0 . .1$ reference|ref|r :doc.id, $0 . .1$ reference2|ref2|r2 :doc.id) are used if intended. The AVD class is defined by the doc link table, which is one for the entire database, and has three secondary keys. The AVD object is implemented by listing the data in one row of the link table.

In describing a hierarchical data structure, it is possible to use an attachment as the second parameter, for example $\mathrm{d}\{, \mathrm{d}\{\}\}$ will mean a structure with a second level hierarchy. It is possible to use the numbers $\mathrm{d}\{, 3 \mathrm{~d}\{\}\}$ to abbreviate the depth of attachment or $d\{3-5 \mathrm{~d}\{\}\}$ to describe the depth range.

Generally, the third parameter (ref) is used to refer to a data type, for example, FHIR, and the fourth parameter (ref2) is to refer to dictionary data.

An additional AVD parameter provides data typing by linking to a data type table (fifth key) that has its own hierarchical links of parent nodes. The type parameter defines simple node data or object \{\} for complex data types. A parameter of type [] denotes a data array. Re-defining simple types with an array|[]\| [].* reference indicates that this AVD is a data array of the appropriate type. A hierarchical combination of AVD nodes of types \{\} and [] provides the ability to generate arbitrary complexity JSON document in MCR-DB model.

The supplemental content table, "docbody", can store the various software structures needed to accelerate the FHIR work and implementation: a JSON document (which has a data structure generated elsewhere in the MCR-DB), SQL templates (data selection procedures for executing expressions and action plan procedures), HTML blocks (for submitting data and for constructing the user interface according to their content).

Ensuring terminological compliance. The correspondence of ICD-10 vocabularies and the FHIR terminology module is implemented by means of the defined connections of these two systems (Fig. 2):

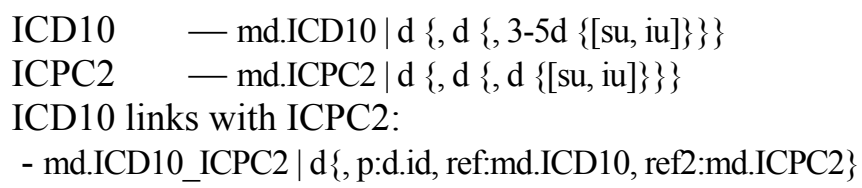




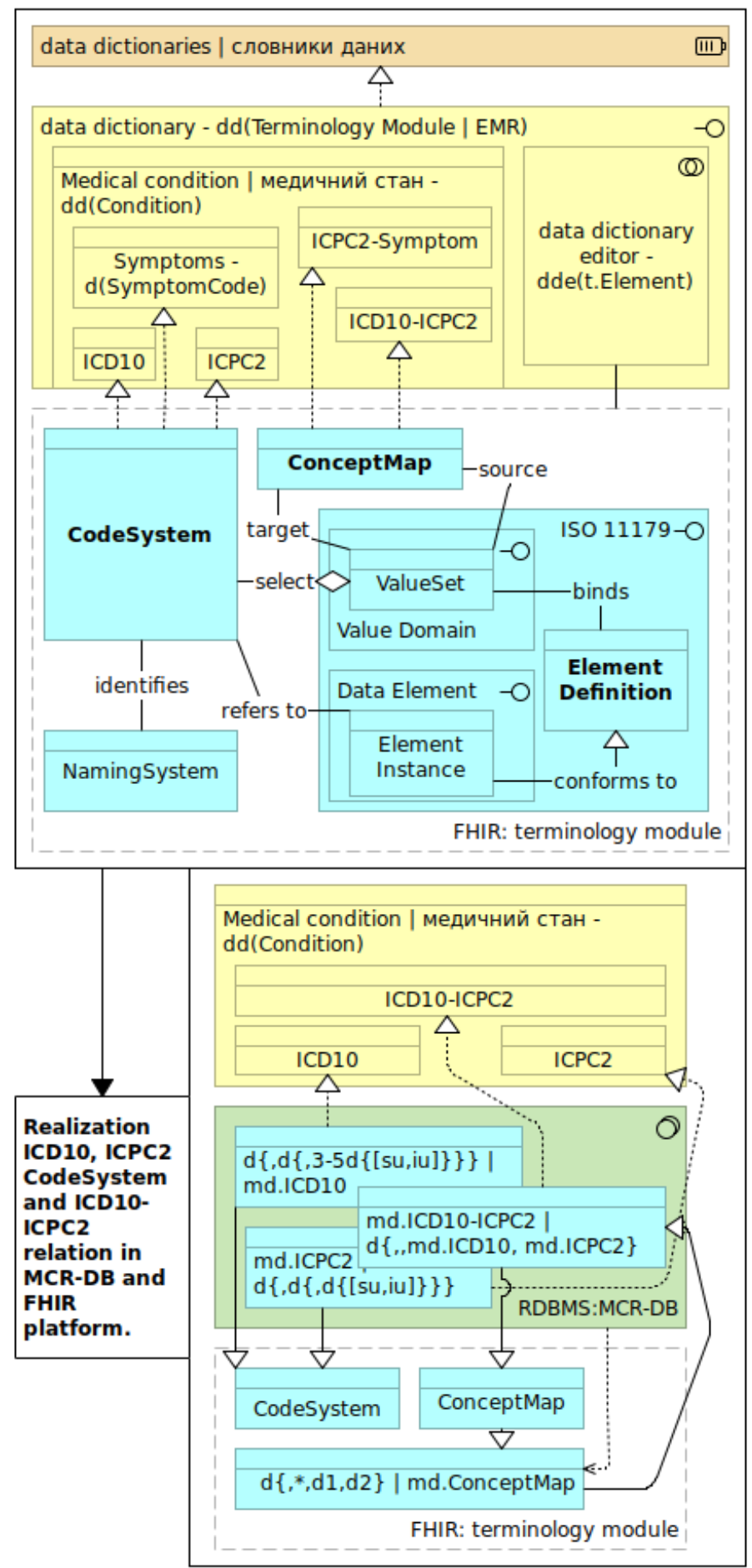

Fig. 2. Use of FHIR terminology module and implementation of MKH-10 classifiers (ICD10, ICPC2) and ICD10-ICPC2 ratios in MCR-DB and FHIR platform 


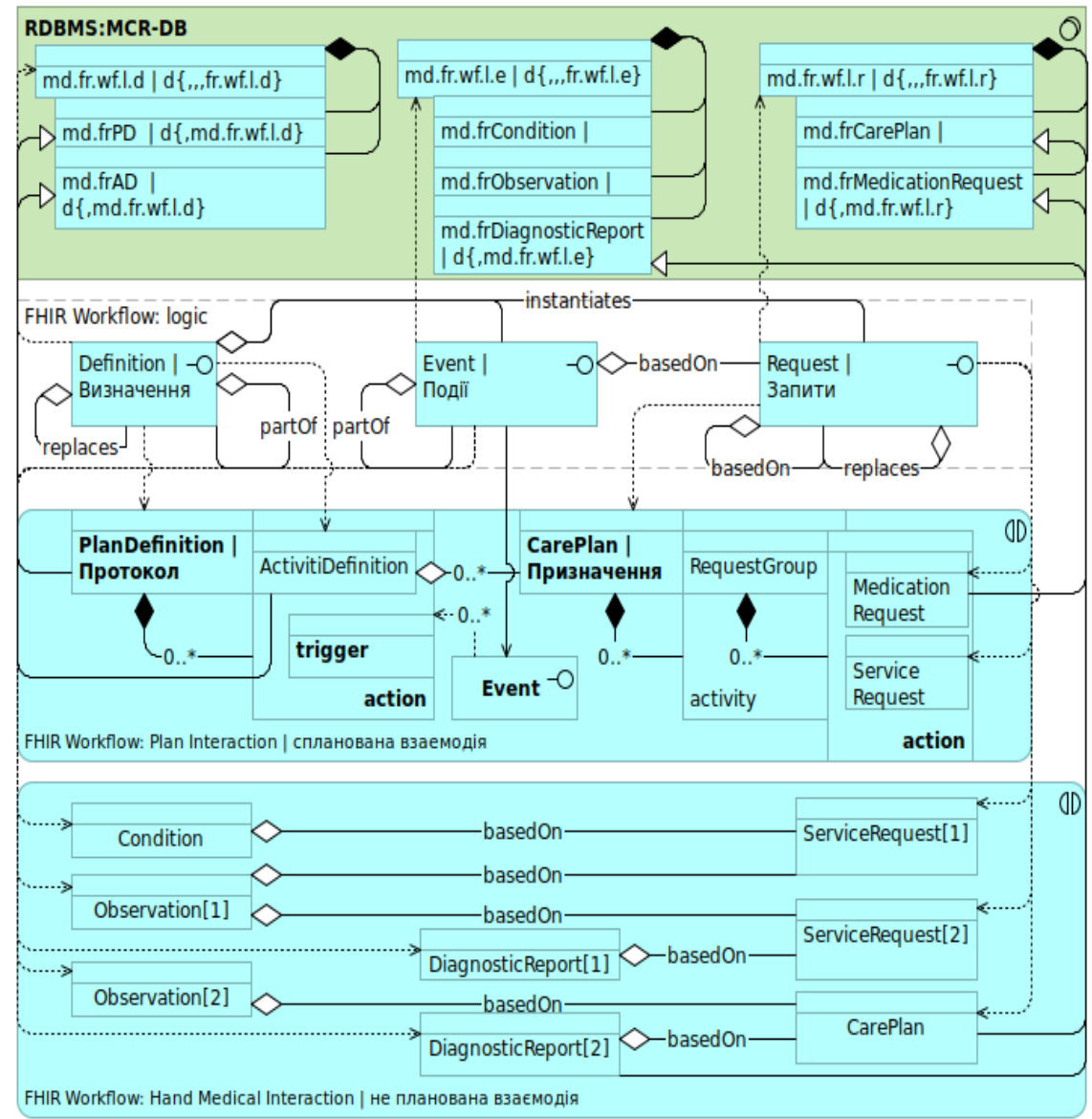

Fig. 3. FHIR: Workflow - RDBMS: MCR-DB

This procedure is organized using the FHIR ConceptMap metadata implemented by the MCR-DB pseudo-expression ADN md.ConceptMap $\mid \mathrm{d}\left\{,{ }^{*}\right.$, ref: $\mathrm{d} 1$.id, ref2: d2.id:\}.

Implementation of the Workflow data modelin nMCR-DB pseudoexpressions (Fig. 3). The logic of Workflow in FHIR is embedded and described in three corresponding logical structures: Definition, Request and Event. These structures have properties similar to the interface in Java object-oriented programming. Using nMCR-DB, we can classify them as metadata by means of the following statements:

ADN.type fr.wf.l. * |FHIR.Workflow.logic. *;

ADN d \{,", type: fr.wfl.d $\} \mid$ md.fr.wf.l.d | FHIR.Definition;

ADN d \{,,,type: fr.wfl.r $\} \mid$ md.fr.wf.l.r| FHIR.Request;

ADN d \{,", type: fr.wfl.e $\} \mid$ md.fr.wf.l.e $\mid$ FHIR.Event;

At the same time, the following classes are indicated accordingly the following statements:

md.frPlanDefinition $\mid$ md.frPD $\mid \mathrm{d}\{,$, fr.wf.l.d $\}$;

md.frActivitiDefinition $\mid$ md.frAD $\mid \mathrm{d}\{$, fr.wf.l.d $\}$.

ISSN 2663-2586 (Online), ISSN 2663-2578 (Print). Cyb. and comp. eng. 2019.№ 4 (198) 
The FHIR Framework's Workflow recommendations apply event-oriented programming approaches and software design pattern principles. In the FHIR Workflow: Plan Interaction ( Fig. 3) shows part of the pattern, by which implementing an event-oriented programming approach is suggested to organize the treating process support.

\section{THE UNITY OF FHIR ORGANIZATIONAL APPROACHES AND CLINICAL DECISION SUPPORT SYSTEMS FOR IMPROVING THE HEALTH CARE QUALITY}

The CDSS-FHIR approach practically provides a model software framework that is generally consistent with the quality management model of the decision support system for improving the care quality.

The generalized strategy is inherently the PDCA Demur model taking into account motivational aspects (Fig. 4). The planning function corresponds with the clinical guidelines implemented in the format of the FHIR PlanDefinition.

In the two approaches under consideration, the use of the audit and the connection with the official medical documents are almost identical.

In the implementation of these methods, during the construction of the relevant information system, the data gathering functions were defined for different information: concerning the course of the disease and the results of the main and auxiliary treatment processes, processing, analysis, transfer of the received information for use in decision-making at different levels of assessment management of care quality and effectiveness.

Thus, the system is intended for use by treating physicians, heads of clinical departments according to the distribution of functional responsibilities, as well as nonclinical unit managers and their staff involved in the supportive processes.

Peculiarities of the systems` organizational structure are deep involvement of staff in quality management, that is why the system is distinguished: the first level of management - executors (self-management), the second level - heads of departments and heads of structural units, the third level - hospital management. In addition, the quality management system includes a number of matrix control structures. The object of management is the complex of processes, i.e. basic (medical care) and ancillary (security and organizational) processes.

The functioning of the system is ensured by the information flow between the participants of the control process in both directions. The information is the result of the collection, evaluation and analysis of data concerning the course of the disease, as well as the effectiveness and efficiency of treating processes. This information is internal, that is, information from one's own sources. External information includes policy and scientific information as well as information on the medical audits results.

All types of information and means for its automated collection, processing and analysis for later use at any level of control of any matrix structure are reflected in the control unit.

Information from one's own sources is formed on the basis of data about events at the processes "key points" and points of their interaction with each other and with the external environment. It is the information that is important for evaluating the effectiveness and efficiency of health care delivery processes. 


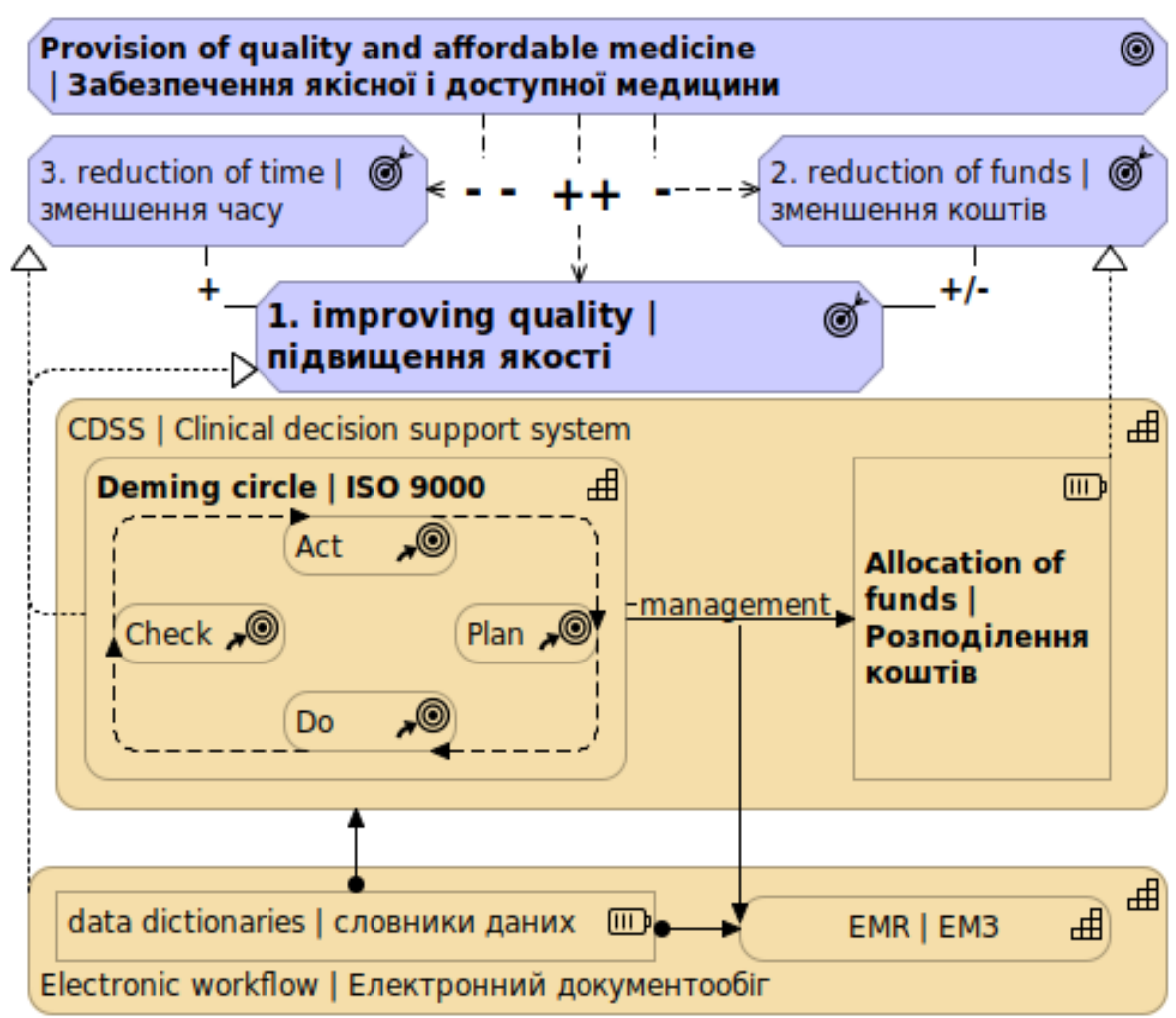

Fig. 4. The generalized strategy for improving the health care quality

As sources of information are as follows: "Medical card of inpatient patient" (f. № 003/o), filled according to the requirements, including information about the result of treatment (recovery, clinical condition improvement, clinical condition without changes, worsening of clinical status, compensation of chronic disease exacerbation, chronic disease subcompensation, fatal consequences), "Statistical card of the patient who left the hospital" (f. № 066/o), filled in according to the requirements, "Extract from the medical card of the inpatient patient" (f. № 027/o), "Procedure Log" with the patient's identification, "Diagnostic and Treatment Card" according to the established quality indicators.

In health care facilities where clinical decision support systems are planned, regulations of local level processes should be worked out and implemented in accordance with the established requirements: clinical protocols of medical care, drug lists, clinical routes of patients, technical standards for governing the main and ancillary processes.

The local clinical care protocol is a document that defines the requirements for diagnostic, treatment, prophylactic and rehabilitation measures, their interrelation and the sequence of implementation in a clinical facility. The local clinical protocol allows physicians to apply the most clinically and cost-effective medicines with the lowest side effects risk. The clinical route of the patient is an organizational component of the health care providing. 
The criteria for the care quality assessing are not only reference point for data collection, but are also used as a guide for further evaluating the performance level of the relevant process. These criteria are divided into organizational and technological. Organizational criteria make it possible to evaluate the degree of compliance with organizational standards, and technological ones - with clinical regulations.

Therefore, clinical decision support systems are based on the knowledge of the means of support and correction of patients' health, accumulate the results of observations of changes in health state under different conditions, and make it possible to evaluate the care delivery quality for the further improvement the health care personnel. CDSSs are regarded as active knowledge systems that allow using a range of professional expertise to generate specific medical suggestions for diagnostic and treatment processes.

\section{CONCIUSIONS}

One of the important areas of eHealth development is to implement the information systems for care quality managing based on modern information medical standards. Creation and implementation of effective methods for identifying diagnostic and monitoring treatment quality in hospital will foster optimization and increase of their activity efficiency.

The use of the FHIR framework in the creation of information support system for evaluating the care delivery quality enables to improve the data exchange quality and their processing for decision-making.

\section{REFERENCES}

1. Hynes D.M., Perrin R.A, Rappaport S., Stevens J.M., Demakis J.G. Informatics Resources to Support Health Care Quality Improvement in the Veterans Health Administration. Journal of the American Medical Informatics Association. V.11, iss. 5. 2004. P. 344-350.

2. Campanella P., Lovato E., Marone C., Fallacara L., Mancuso A., Ricciardi W., Specchia M.L. The impact of electronic health records on health carequality: a systematic review and meta-analysis. European Journal of Public Health. 2016. V. 26, no 1. P. 60-64. https://doi.org/10.1093/eurpub/ckv122.

3. Heller B., Krüger M., Löffler M., Mantovani L., Meineke F., Mishchenko R. OncoWorkstation - Ein adaptives Agentensystem für das Therapiemanagement klinischer Studien 2002, Berlin.;

4. Meineke, F., Mishchenko, R., Mantovani, L., Löffler, M. \& Heller, B. Onco-Workstation - ein Konsultations- und Planungswerkzeug zur Unterstützung der Auswahl und Durchführung von onkologischen Therapiestudien. In: Jahrestagung der GMDS. Informatik, Biometrie und Epidemiologie in Medizin und Biologie, 2003, pp. 374.

5. Voronenko Yu., Gorachuk V. Management of quality of medical care: world and domestic models. Eastern European Journal of Public Health. 2012. No. 2-3 (18-19). P. 64-67. (in Ukranian)

6. Voronenko Yu., Gorachuk V. Methodical approaches to implementation of standardization of organizational technologies in the quality management system of medical care. Ukrainian Medical Journal. 2012. No. 5(91). P. 108-110. (in Ukranian)

7. Gorachuk V., Bogatir I. Experience in the development and implementation of an information system for monitoring the quality of care. Medical Forum. 2014. no 2. P. 55-59. (in Ukranian)

8. Kovalenko O.S., Kozak L.M., Romanyuk O.A. Digital Medicine Information Technology. Kibernetika i vyčislitelnaâ tehnika. 2017. No. 1(187). P. 69-79. (in Russian) 
9. Rogozinskaya N.S., Kozak L.M. Information support of technology for automated monitoring of the state of public health. Kibernetika i sistemnyj analiz, 2013, no. 6, pp. $162-173$.

10. Kozak L.M., Kovalenko O.S., Romanyuk O.A, Antomonov M.Yu. Formation of Information Medical Environment in Different Levels. Proc. SPIE. 11176, Photonics Applications in Astronomy, Communications, Industry, and High-Energy Physics Experiments. 2019, 6 November 2019.

11. Impact of Heath Information Technology on the Quality of Patient Care. OJNI. V. 19. 2015.

12. Kozak L.M., Kovalenko A.S., Kryvova O.A., Romanyuk O.A. Digital Transformation in Medicine: From Formalized Medical Documents to Information Technologies of Digital Medicine. Kibernetika i vyčislitelnaâ tehnika. 2018. no. 4(194). P. 61-78.

13. Ross D. S., Venkatesh R. Role of Hospital Information Systems in Improving Healthcare Quality in Hospitals. Indian Journal of Science and Technology. 2016. v. 9(26). P.1-5.

14. Crosson J.C., Stroebel C., Scott J.G., Stello B., Crabtree B.F. Implementing an Electronic Medical Record in a Family Medicine Practice: Communication, Decision Making, and Conflict. Annals of Family Medicine. 2005. Vol. 3. no. 4. P. 7-11.

15. Coiera E., Westbrook J.I., Wyatt J.C. The Safety and Quality of Decision Support Systems. URL: https://www.researchgate.net/publication/6745100 (Last accessed: 05.09.2019.)

16. HL7 Messaging Standard Version 2.7. URL: http://www.hl7.org/ implement/standards/product_brief.cfm?product_id?146. (Last accessed: 01.09.2018).

17. Mandel J.C., Kreda D.A., Mandl K.D., Kohane I.S., Ramoni R.B. SMART on FHIR: a standards-based, interoperable apps platform for electronic health records. Journal of the American Medical Informatics Association Advance Access. 2016. P.1-10.

18. Version History since DSTU \#1 URL: https://build.fhir.org/history.htm (Last accessed: 08.08.2019.)

19. How FHIR works and what's a FHIR resource.URL: https://searchhealthit.techtarget.com/definition/FHIR-Fast-Healthcare-InteroperabilityResources (Last accessed: 08.08.2019.)

20. Bender D, Sartipi K. HL7 FHIR: anagile and REST ful approach to health care information exchange. In IEEE 26th International Symposiumon Computer-Based Medical Systems (CBMS). 2013. P. 326-331.

21. Zhemchugov A.M., Zhemchugov M.K. PDCA Deming cycle. Modern development. Problems of economy and management. 2016. no. 2 (54). P.3-28. (in Russian)

\section{ЛІТЕРАТУРА}

Received 21.08.2019

1. Hynes D.M., Perrin R.A, Rappaport S., Stevens J.M., Demakis J.G. Informatics Resources to Support Health Care Quality Improvement in the Veterans Health Administration. Journal of the American Medical Informatics Association. V.11. iss. 5. 2004. P. 344-350.

2. Campanella P., Lovato E., Marone C., Fallacara L., Mancuso A., Ricciardi W., Specchia M.L. Theimpact of electronic health records on health carequality: a systematic review and meta-analysis. European Journal of Public Health. 2016. V. 26. No. 1. P. 60-64, https://doi.org/10.1093/eurpub/ckv122.

3. Heller B., Krüger M., Löffler M., Mantovani L., Meineke F., Mishchenko R. OncoWorkstation - Ein adaptives Agentensystem für das Therapiemanagement klinischer Studien 2002, Berlin.

4. Meineke, F., Mishchenko, R., Mantovani, L., Löffler, M. \& Heller, B. Onco-Workstation - ein Konsultations- und Planungswerkzeug zur Unterstützung der Auswahl und Durchführung von onkologischen Therapiestudien. In: Jahrestagung der GMDS. Informatik, Biometrie und Epidemiologie in Medizin und Biologie, 2003, pp. 374.

5. Вороненко Ю., Горачук В. Управління якістю медичної допомоги: світові та вітчизняні моделі. Східноєвропейський журнал громадського здоров’я. 2012, № 2-3 (18-19). С. 64-67. 
6. Вороненко Ю., Горачук В. Методичні підходи до впровадження стандартизації організаційних технологій у систему управління якістю медичної допомоги. Український медичний часопис, 2012. № 5(91), С. 108-110.

7. Горачук В., Богатир I. Досвід розробки та впровадження інформаційної системи моніторингу якості медичної допомоги. Медичний форум. 2014. № 2. С. 55-59.

8. Коваленко А.С., Козак Л.М., Романюк О.А. Информационные технологии цифровой медицины. Киб. и выч. техн. 2017, №1(187). С.67-79.

9. Рогозинская Н.С., Козак Л.М. Информационная технология исследования состояния здоровья населения региона. Управляющие системыл и машины. № 6. 2013. 59-67

10. Kozak L.M., Kovalenko O.S., Romanyuk O.A, Antomonov M.Yu. Formation of Information Medical Environment in Different Levels. Proc. SPIE. 11176, Photonics Applications in Astronomy, Communications, Industry, and High-Energy Physics Experiments. 2019, 6 November 2019.

11. Impact of Heath InformationTechnology on the Quality of Patient Care. OJNI. 2015, т. 19.

12. Kozak L.M., Kovalenko A.S., Kryvova O.A., Romanyuk O.A. Digital Transformation in Medicine: From Formalized Medical Documents to Information Technologies of Digital Medicine. Киб. и выч. техн. 2018. 4(194). C. 61-78.

13. Ross D.S., Venkatesh R. Role of Hospital Information Systems in Improving Healthcare Quality in Hospitals. Indian Journal of Science and Technology. 2016. V. 9(26). C.1-5.

14. Crosson J.C., Stroebel C., Scott J.G., Stello B., Crabtree B.F. Implementing an Electronic Medical Record in a Family Medicine Practice: Communication, Decision Making, and Conflict. Annals of Family Medicine. 2005. Vol. 3. no. 4. C. 7-11.

15. Coiera E., Westbrook J.I., Wyatt J.C. The Safety and Quality of Decision Support Systems. URL: https://www.researchgate.net/publication/6745100 (Дата звернення: 05.09.2019.)

16. HL7 Messaging Standard Version 2.7. Інформаційний ресурc: http://www.hl7.org/ implement/standards/product_brief.cfm?product_id?146. (Дата звернення: 01.09.2018).

17. Mandel J.C., Kreda D.A., Māndl K.D., Kohane I.S., Ramoni R.B. SMART on FHIR: a standards-based, interoperable apps platform for electronic health records. Journal of the American Medical Informatics Association Advance Access. 2016. C.1-10.

18. Version History since DSTU \#1 URL: https://build.fhir.org/history.htm (Дата звернення: 08.08.2019.)

19. How FHIR works and what's a FHIR resource. URL: https://searchhealthit.techtarget.com/ definition/FHIR-Fast-Healthcare-InteroperabilityResources (Дата звернення: 08.08.2019.)

20. Bender D, Sartipi K. HL7 FHIR: anagile and REST ful approach to health care information exchange. In IEEE 26th International Symposiumon Computer-Based Medical Systems (CBMS). 2013. C. 326-331.

21. Жемчугов А.М., Жемчугов М.К. Цикл PDCA Деминга. Современное развитие. Проблемы экономики и менеджмента. 2016. № 2 (54). С.3-28.

Отримано 21.08.2019 
Коваленко О.С. ${ }^{1}$, д-р мед. наук, проф., зав. відд. медичних інформаційних систем e-mail: askov49@gmail.com

Міщенко P..$^{2}$, канд.мед.наук, лікар інформаційно-аналітичного відд. медичної статистики e-mail: roman.mishchenko@gmail.com

Козак Л.М. , д-р біол. наук, старш. наук. співроб., пров. наук. співроб. відд. медичних інформаційних систем e-mail:1mkozak52@gmail.com

${ }_{1}^{1}$ Міжнародний науково-навчальний центр інформаційних технологій та систем НАН України та МОН України, пр. Акад. Глушкова, 40, м. Київ, 03187, Україна

${ }^{2}$ Хмельницька обласна лікарня, вул. Пілотська, 1, Хмельницький, 29000, Украина

\section{ПЕРЕХІД СИСТЕМ ПІДТРИМКИ ПРИЙНЯТТЯ КЛІНІЧНИХ РІШЕНЬ B FHIR СТРУКТУРИ ДЛЯ ЗАБЕЗПЕЧЕННЯ ЯКОСТІ МЕДИЧНОЇ ДОПОМОГИ}

Вступ. Реформа медичної галузі в Україні зробила поштовх до розвитку електронної охорони здоров'я i, як наслідок, створення системи медичних реєстрів та спеціалізованих медичних інформаційних систем підтримки функціонування первинної медичної допомоги тощо. Одним зі стратегічних напрямків системи охорони здоров'я $є$ пошук і вибір ефективних методів керування якістю медичної допомоги.

Мета статті - аналіз умов та можливостей трансформації системи підтримки прийняття клінічних рішень з використанням структур інформаційної швидкодії Fast Healthcare Interoperability Resources (FHIR) для забезпечення контролю якості медичної допомоги.

Результати. Сучасний рівень розроблення медичних інформаційних систем зумовлює застосування міжнародного стандарту FHIR - ресурс швидкої взаємодії в галузі охорони здоров'я, який використовується для обміну даними як між різними системами електронних медичних записів, так і між різними компонентами однієї ЕМЗ-системи, для стандартизації інтероперабельності. Розглянуто модель безперервного поліпшення якості процесу, відомої як цикл Демінга (Plan-Do-Check-Act (PDCA)), який складається з чотирьох складників планування, виконання, перевірки і вдосконалення цього процесу.

Проаналізовано характеристики стандарту FHIR та визначено шляхи трансформації системи підтримки прийняття клінічних рішень на основі цього стандарту. Описано Поняття абстрактного вузла даних, Забезпечення термінологічної відповідності, Імплементацію моделі даних Workflow та інші функції та завдання системи підтримки прийняття клінічних рішень.

Висновки. Одним із важливих напрямів розвитку eHealth $€$ впровадження інформаційних систем керування якістю надання медичної допомоги на основі сучасних інформаційних медичних стандартів. Створення та впровадження ефективних методів моніторингу (виявлення) якості діагностики та лікування сприятиме оптимізації та підвищенню ефективності діяльності закладів охорони здоров'я. Використання стандарту FHIR у створенні системи інформаційної підтримки для оцінювання якості надання послуг дає змогу покращити якість обміну даними та їхнє оброблення для прийняття рішень.

Ключові слова: eHealth, структури FHIR, система підтримки прийняття клінічних рішень, контроль якості охорони здоров'я. 
Коваленко А.C. ${ }^{1}$, д-р мед. наук, проф., зав. отд. медицинских информационных систем e-mail: askov49@gmail.com

Мищенко Р.Ф. ${ }^{2}$, канд.мед.наук,

врач информационно-аналитического отд. медицинской статистики e-mail: roman.mishchenko@gmail.com

Козак Л.М. ${ }^{1}$, д-р биол. наук, старш. науч. сотр., вед. науч. сотр. отд. медицинских информационных систем e-mail:1mkozak52@gmail.com

${ }^{1}$ Международный научно-учебный центр информационных технологий и систем НАН Украины и МОН Украины, пр. Акад. Глушкова, 40, г. Киев, 03187, Украина

${ }^{2}$ Хмельницкая областная больница, ул. Пилотская, 1, г. Хмельницький, 29000, Украина

\section{ТРАНСФОРМАЦИЯ СИСТЕМ ПОДДЕРЖКИ ПРИНЯТИЯ КЛИНИЧЕСКИХ РЕШЕНИЙ В FHIR СТРУКТУРЫ ДЛЯ ОБЕСПЕЧЕНИЯ КАЧЕСТВА МЕДИЦИНСКОЙ ПОМОЩИ}

Современный уровень разработки медицинских информационных систем обуславливает применение международного стандарта Fast Healthcare Interoperability Resources (FHIR) - pесурс быстрого взаимодействия в области здравоохранения, который используется для обмена данными как между различными системами электронных медицинских записей, так и между различными компонентами одной системы для стандартизации интероперабельности. Рассмотрена модель непрерывного улучшения качества процесса, известная как цикл Деминга (Plan-Do-Check-Act (PDCA)), который состоит из четырех частей - планирование, исполнение, проверка и совершенствование этого процесса.Проанализированы характеристики стандарта FHIR и определены пути трансформации системы поддержки принятия клинических решений на основе этого стандарта. Описаны понятие абстрактного узла данных, обеспечение терминологического соответствия, имплементация модели данных Workflow и другие функции и задачи системы поддержки принятия клинических решений.

Ключевые слова: электронное здравоохранение, структуры FHIR, система поддержки принятия клинических решений, контроль качества здравоохранения. 